J. Asiat. Soc. Bangladesh, Sci. 44(2): 117-125, December 2018

\title{
YIELD AND BIOCHEMICAL ATTRIBUTES OF BRRI DHAN-44 (ORYZA SATIVA L.) AS AFFECTED BY TIBA APPLICATION
}

\author{
A. M. M. GOLAM ADAM*, RASEDUL ISLAM AND HASNA HENA BEGUM \\ Department of Botany, Jagannath University, Dhaka-1100, Bangladesh
}

\begin{abstract}
A pot experiment was carried out to evaluate the effect of different concentrations $(0,10$, 25, 50 and $100 \mathrm{ppm}$ ) of TIBA on yield and biochemical attributes of BRRI dhan-44. Results revealed that number of effective tillers and dry weight of panicle per plant, length of panicle, number of grains per panicle, 1000-grain weight, yield per plant and harvest index increased due to all concentrations of TIBA treatments where, treatments mean varied significantly in majority of cases. The stimulatory effect of TIBA treatments on number of effective tillers and dry weight of panicles per plant, length of panicle, number of grains per panicle and 1000-grain weight resulted significant increase in grain yield per plant. The maximum yield per plant (17.83 g) was obtained from $10 \mathrm{ppm}$ TIBA treatment which was $59.76 \%$ higher over the control. Increases in yield per plant due to 25, 50 and 100 ppm TIBA were 50.53, 47.58 and 28.49\%, respectively. Findings of this investigation showed that foliar application of TIBA had beneficial effect on pigment content of leaves at tillering and grain filling stages with a few exceptions. Protein content of leaves was also positively influenced by most of the treatment at tillering stage. Out of five treatments, $10 \mathrm{ppm}$ TIBA produced better results.
\end{abstract}

Key words: BRRI dhan-44, TIBA, Foliar application, Yield, Biochemical attributes

\section{Introduction}

Rice (Oryza sativa L.) is the chief food of the people of Bangladesh which contributes about $92 \%$ of the total food grains produced in the country (Chowdhury and Hassan 2013). The demand for rice is persistently rising in our country with nearly 2.3 million people being added each year to its population (Zohir et al. 2002). But, the problem of land scarcity is being compounded by land degradation as there is almost no scope for bringing new land under cultivation. In addition, drought, lack of irrigation facilities, flooding and salinity of soils are the main constraints for better production. Demand of rice can be achieved through the number of agronomic techniques viz. selection of high yielding and disease resistant varieties, hybridization, improved cultural practices, proper application of fertilizers, use of growth regulating substances etc. Deficiency of plant growth regulators at any stage of plant growth may create a genetical or environmental barrier in attaining maximum growth and yield. Moreover, these organic substances have been used for many years to boost up crop production.

\footnotetext{
*Author for correspondence: E-mail: adam_du04@yahoo.com
} 
Results of several investigations of the world revealed that application of 2,3,5 tri-iodo benzoic acid (TIBA) have potential effects in modifying growth, yield and biochemical component of several economically important plants (Phillips and Chilcote 1981, Ravichandran and Ramaswami 1991, Kler and Dhillon 1993, Rahman and Rahman 1997, Mondal and Dutta 2002, Djanaguiraman et al. 2005, Surendra et al. 2006, Abdelgadir et al. 2009). But, research work regarding the effect of TIBA on cereals crops is limited from elsewhere of the world and also in Bangladesh (Munira 2015, Adam et al. 2015). Hence, the present work was under taken to evaluate the effect of TIBA on yield and biochemical component of BRRI dhan-44.

\section{Materials and Methods}

A pot experiment was conducted at the botanical garden of the Department of Botany, Jagannath University, Dhaka. Earthen pots of uniform size was filled with $9.0 \mathrm{~kg}$ air dried soil. The soil used in this experiment was clay loam in texture. Urea, triple super phosphate, muriate of potash and gypsum were applied at doses recommended by BRRI. Cowdung was also mixed homogeneously during preparation of the pots. The experiment was laid out in a randomized complete block design (RCBD) with five replications. Seeds of BRRI dhan-44 were collected from Bangladesh Agricultural Development Corporation (BADC). It is a high yielding Aman variety, very popular to the farmers of southern part, and also suitable for non-saline tidal zone. Seeds were sterilized with $0.05 \%$ calcium hypochlorite solution for two minutes before sowing. Seedlings were transplanted to experimental pots at the age of 40 days after sowing. Three hills were placed in each pot, where each hill contains one seedling. Thinning, weeding and irrigation were done as per necessity. Split applications of urea were done twice at the rates of $2 \mathrm{~g}$ per pot at 24 and 54 days after transplanting (DAT). There were five foliar treatments viz. 0 (control), 10, 25, 50 and $100 \mathrm{ppm}$ TIBA. Treatments were applied in sunny early morning at 32 DAT. During spraying, precautionary measures were taken to avoid crossing of growth regulator from one treatment to another.

Plants (BRRI dhan-44) were harvested at the age of 120 DAT. During harvesting 10 plants of each treatments were randomly selected to record data on number of effective and non-effective tillers per plant, dry weight of panicles per plant, length of panicle, number of grains per panicle, $\%$ of filled and un-filled grains per panicle, 1000-grain weight, yield per plant and harvest index. Yield per plant was calculated according to the formula of ICRISAT (1992). Chlorophyll a and b, carotenoid and protein contents of leaves were determined at three different stages viz. tillering, flowering and grain filling stages. The amount of chlorophyll $\mathrm{a}$ and $\mathrm{b}$ were determined by using specific absorption 
co-efficient of Mckinney (1940) and the formulae of Maclachalan and Zalik (1963). The amounts of carotenoid was calculated using the equation of von Wettstein (1957). The method of Lowry et al. (1951) was employed for the determination of protein content of leaves. Data were analyzed statistically and treatment means were compared by LSD test at 5\% level of significance (Steel et al. 1997).

\section{Results and Discussion}

Results presented in Table 1 showed that number of effective tiller per plant increased due to all treatments and the maximum increase was recorded from $100 \mathrm{ppm}$ which was $48.38 \%$ higher over the control followed by $10 \mathrm{ppm}$. TIBA treatment. Whereas, in case of non-effective tillers per plant better response was obtained from 50 and 100 ppm TIBA treatments. Reports of Misra and Sahu (1958) revealed that the number of panicles per plant was increased due to 250 and 500 ppm TIBA application. Similar results of increase were also recorded in other plants by several investigators (Chung and Kim 1989, Ravichandran and Ramaswami 1991, Rahman and Rahman 1997, Mondal and Dutta 2002, Djanaguiraman et al. 2005).

Present investigation also showed that dry weight of panicles increased following all treatments and the maximum obtained from 10 ppm. Findings of Munira (2015) revealed significant increase in dry weight of cob due to TIBA application in BARI Maize-6. Similar results of increase due to TIBA application were also reported in different plants by other workers (Jahan and Khan 2014, Adam and Jahan 2014).

Results indicated that significantly higher length of panicle was obtained from the plants of 10 and $25 \mathrm{ppm}$ treatments although statistically at par to 50 and $100 \mathrm{ppm}$. The maximum increase due to $10 \mathrm{ppm}$ was $17.08 \%$. Length of panicle was also found to increase following both 50 and $100 \mathrm{ppm}$ treatments but statistically similar to control. Increases in length of pods due to TIBA application were reported by Munira (2015) in BARI Maize-6 and Adam and Jahan (2014) in BARI Mung-5. However, Misra and Sahu (1958) did not find any significant changes due to TIBA application on rice plant.

Results revealed that number of grains per panicle of BRRI dhan-44 responded positively following all treatments and increased significantly due to 10 and $100 \mathrm{ppm}$ treatments. Misra and Sahu (1958) obtained increased number of grains per panicle from $100 \mathrm{ppm}$ TIBA treated rice plant. Number of karnels per cob increased following TIBA application in BARI Maize-6 (Munira 2015). These results are also in conformity with the findings of other workers (Dholekar et al. 2001, Jahan and Khan 2014, Adam and Jahan 2014). 
In the present investigation, per cent of filled grains per panicle increased due to all treatments except $100 \mathrm{ppm}$ TIBA treatment. The maximum per cent filled grains per panicle was obtained from $25 \mathrm{ppm}$ treatment although statistically at par to rest of the treatments. Application of TIBA had also beneficial effect on per cent of un-filled grains per panicle with an exception of $100 \mathrm{ppm}$ treatment. By applying different concentration of TIBA, Misra and Sahu (1958) found increased percentage of grain setting where, variation was significant due to $100 \mathrm{ppm}$ treatment.

Results showed that weight of 1000-grain increased due to all rates of TIBA treatments in BRRI dhan-44. The maximum 1000-grain weight was obtained from $10 \mathrm{ppm}$ which was significantly different from control but similar to $25 \mathrm{ppm}$ treatment. Munira (2015) reported that 1000-grain weight increased following all concentration of TIBA treatments in BARI Maize-6 where, significantly highest value was obtained from 25 ppm treated plants. However, findings of Misra and Sahu (1958) did not observe any significant effect of TIBA on 1000-grain weight of rice. Similar results of increases in seed weights following TIBA application were also reported by other investigators (Ravichandran and Ramaswami 1991, Jahan and Khan 2014). Thus, the results obtained during the present study are in accord with the findings of previous workers.

Results of the present investigation revealed that yield of BRRI dhan-44 was significantly higher following all concentrations of TIBA treatments. The maximum yield per plant $(17.83 \mathrm{~g})$ was obtained from $10 \mathrm{ppm}$ treatment and it was $59.76 \%$ higher over the control followed by 25, 50 and $100 \mathrm{ppm}$, respectively. Increases in yield per plant due to 25, 50 and $100 \mathrm{ppm}$ were 50.53, 47.58 and 28.49\%, respectively. Mishra and Sahu (1958) reported that TIBA induced yield at 100 to $250 \mathrm{ppm}$ in mid- and late-winter varieties of rice by increasing the number of grains per panicle and percentage of seed-setting. Yield of BARI Maize-6 increased following different concentration of TIBA treatment and were significant due to 50 and $75 \mathrm{ppm}$ treatments (Munira 2015). Application of different concentrations of TIBA had also beneficial effect on yield of different plants viz. ground nut (Kler and Dhillon 1993), safflower (Dholekar et al. 2001), tomato (Razzaque and Rahman 2004), cotton (Djanaguiraman et al. 2005), soybean (Jahan and Khan 2014), mungbean (Adam and Jahan 2014). Thus, the findings of the present investigation are in conformity with the findings of many other investigators who have observed that yield of TIBA treated plants may increase depending on the concentrations used and also on the plants.

Results showed that, harvest index increased following all treatments. The highest harvest index was found from $10 \mathrm{ppm}$ followed by $25 \mathrm{ppm}$ treatment. Foliar application 


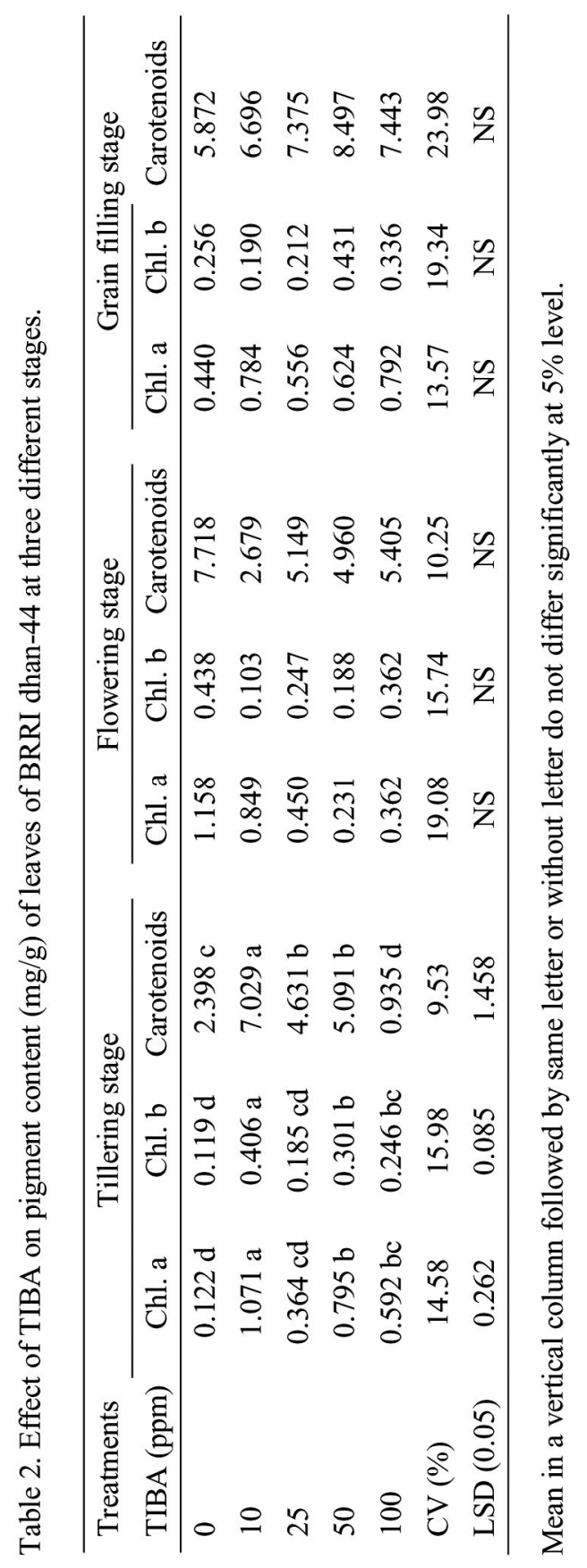


of 75 ppm TIBA resulted the maximum harvest index in BARI Maize- 6 followed by 25 ppm treatment (Munira 2015) whereas, Adam and Jahan (2014) found highest harvest index with $20 \mathrm{ppm}$ TIBA treatment.

Results obtained during the present investigation showed that the amount of chlorophyll $\mathrm{a}, \mathrm{b}$ and carotenoids content of BRRI dhan-44 were found to increase at tillering and grain filling stages having few exceptions, whereas, decreased at flowering stage following all treatments (Table 2). Pigment content of leaves significantly increased due to all application of TIBA treatment at tillering stage except carotenoids content due to $100 \mathrm{ppm}$ treatment where, it was decreased significantly. Results also showed that plants treated with 10 ppm TIBA produced the highest pigment content of leaves. Both increases and decrease in pigment content of leaves following TIBA treatments was reported by Munira (2015) in maize and Jahan and Khan (2014) in soybean. Findings on pigment content of leaves are in conformity with the results of many other investigators who have observed that pigment content of TIBA treated plants may increase or decrease depending on the concentrations used and also on the variety.

Foliar application of TIBA had affirmative response on protein content of leaves at tillering stage with an exception of $25 \mathrm{ppm}$ treatment. Although, protein content of leaves responded negatively at flowering and grain filling stages with significant variations (Table 3). This results are in agreement with the findings of other authors (Jahan and Khan 2014, Munira 2015).

Table 3. Effect of TIBA on protein content $(\mathrm{mg} / \mathrm{g})$ of leaves of BRRI dhan-44 at three different stages.

\begin{tabular}{lccc}
\hline Treatments & Tillering stage & Flowering stage & Grain filling stage \\
\cline { 2 - 4 } TIBA $(\mathrm{ppm})$ & \multicolumn{3}{c}{ Amount of protein $(\mathrm{mg} / \mathrm{g})$} \\
\hline 0 & 44.28 & $38.75 \mathrm{a}$ & $7.68 \mathrm{a}$ \\
10 & 61.45 & $21.60 \mathrm{c}$ & $3.50 \mathrm{~b}$ \\
25 & 39.30 & $31.32 \mathrm{~b}$ & $2.95 \mathrm{~b}$ \\
50 & 45.80 & $38.83 \mathrm{a}$ & $2.23 \mathrm{~b}$ \\
100 & 47.75 & $34.18 \mathrm{ab}$ & $2.83 \mathrm{~b}$ \\
CV $(\%)$ & 14.79 & 24.06 & 12.94 \\
LSD $(0.05)$ & NS & 6.85 & 2.02 \\
\hline
\end{tabular}

Mean in a vertical column followed by same letter or without letter do not differ significantly at $5 \%$ level. 
The overall results of this investigation indicated that various concentration of TIBA had mostly stimulatory effect on various yield contributing parameters and finally increased grain yield significantly. Biochemical components responded differently depending on the concentration of TIBA and stage of growth. Among five concentrations of TIBA, 10 ppm produced better outcome.

\section{References}

Abdelgadir, H.A., S.D. Johnson and J. Van Staden. 2009. Promoting branching of a potential biofuel crop Jatropha curcas L. by foliar application of plant growth regulators. Plant Growth Regulation 58(3): 287-295.

Adam, A.M.M.G. and N. Jahan. 2014. Growth and yield of BARI Mung-5 (Vigna radiata L. Wilczek) following TIBA application. Dhaka Univ. J. Biol. Sci. 23(2): 179-185.

Adam, A.M.M. G., R. Islam, H.H. Begum and M.K. Naher. 2015. Growth analysis of BRRI dhan44 (Oryza sativa L.) following 2, 3, 5-Triiodobenzoic (TIBA) acid application. J. Asiatic Soc. Bangladesh, Sci. 41(1): 67-74.

Chowdhury, M.A.H. and M.S. Hasan. 2013. Hand Book of Agricultural Technology. Bangladesh Agric. Res. Council, Farmgate, Dhaka. 230 p.

Chung, I.M. and J.K. Kim. 1989. Effect of plant growth regulator (TIBA, ABA, DGLP) treatment on growth and yield of soybean (Glycine max L.) Korean J. Crop Sci. 34(1): 1-6.

Dholekar, P.D., B.N. Patil and R.S. Shivankar. 2001. Effect of foliar spray of different growth regulators on yield and yield attributes of safflower. Agric. Sci. Digest. 21(4): 241-243.

Djanaguiraman, M., J.A. Sheeba, D.D. Devi and U. Bangarusamy. 2005. Response of cotton to atonik and TIBA for growth, enzyme and yield. J. Biol. Sci. 5(32): 158-162.

ICRISAT 1992. Research Planning and Data Handling. Diwakar, B. and D. L. Oswalt. International crop research institute for semi-arid tropics. Patancheru, Andhra Pradesh, India. $67 \mathrm{p}$.

Jahan, N. and S. Khan. 2014. Effect of TIBA on growth, yield and yield component of soybean. $J$. Asiat. Soc. Bangladesh, Sci. 40(1): 89-96.

Kler, D.S. and G.S. Dhillon. 1993. Effect of cycocel and TIBA spray on the pod yield of groundnut. Environment and Ecology 11(2): 475.

Lowry, O.H., N.J. Rosebrough, A.L. Farr and R.J. Randall. 1951. Protein measurement with folin phenol reagent. J. Boil. Chem. 193: 265-275.

Maclachalan, S. and S. Zalik. 1963. Plastid structure, chlorophyll concentration and free amino acid composition of a chlorophyll mutant of barley. Can. J. Bot. 41: 1053-1062.

Mckinney, G. 1940. Criteria for purity of chlorophyll preparations. J. Biol. Chem. 132: 91-107.

Misra, G. and G. Sahu. 1958. Physiology of growth and reproduction in Rice. II. Effect of plant growth substances on three winter varieties. Pl. Physiol. 34(4): 441-445.

Mondal, M.M.A. and R.K. Dutta. 2002. Effect of TIBA (2,3,5-triiodobenzoic acid) on growth and yield of tomato. J. Agricul. Res. 40(3\&4): 273-279.

Munira, S. 2015. Growth, yield and biochemical responses of BARI Maize-6 (Zea mays L.) as affected by TIBA application. M.Sc. Thesis, Department of Botany, Jagannath University, Dhaka. 
Phillips, J.C. and D.O. Chilcote. 1981. Growth and reproductive development of alfalfa as influenced by 2,3,5-triiodobenzoic acid. Canadian J. Bot. 59: 373-376.

Rahman, M.A. and M.M. Rahman. 1997. Effect of maleic hydrazide and tri-iodo benzoic acid on growth, sex expression and yield of Lagenaria siceraria (Mol.) Standl. J. Asiat. Soc. Bangladesh, Sci. 23(2): 172-178.

Ravichandran, V.K. and C. Ramaswami. 1991. Effect of TIBA on yield and yield components of soybean in different seasons. Haryana J. Agron. 7(2): 120-122.

Razzaque, A.H.M. and M.S. Rahman. 2004. Effect of TIBA on chlorophyll, soluble protein content and yield of tomato. Indian J. Hort. 61(2): 140-142.

Steel, R.G.D., J.H. Torrie and D.A. Dickey. 1997. Principles and procedures of statistics. McGraw Hill Book Co. Inc. New York.

Surendra, P., C.M. Nawalagatti, M.B. Chetti and S.M. Hiremath. 2006. Effect of plant growth regulators and micronutrients on morpho-physiological and biochemical traits and yield in Okra. Karnataka J. Agric. Sci. 19(3): 694-697.

von Wettstein, D. 1957. Chlorophyll-lethal under Submikroskopisoche Formechse der Plastiden. Expt. Cell Res. 12: 427-507.

Zohir, S., Q. Shahabuddin and M. Hossain. 2002. Determination of rice supply and demand in Bangladesh: Recent trends and projection in M. Sombilla, M. Hossain and B. Hardy (eds), Developments in the Asian rice economy, Los Banos, Philippines. Int. Rice Res. Inst. 127-152 pp.

(Revised copy received on 4.7.2018) 